\title{
Global Pandemic as an Innovative Impulse for the Labour Market
}

\author{
Dana Linkeschova ${ }^{1}{ }^{*}$, Alena Ticha ${ }^{1}$, Martin Novy $^{l}$, and Jan Tichy ${ }^{l}$ \\ ${ }^{1}$ BUT, Faculty of Civil Engineering, Institute of Structural Economics and Management, Veveri \\ 331/95, Brno, 60200 Czech Republic
}

\begin{abstract}
Research background: The global history of mankind in an international context is permeated by the painful events include epidemics, wars, natural disasters and crises, including economic ones.

Purpose of the article: According to research, it will be the generation of hatcheries from digital talents. In the work environment, however, centennials behave differently than all previous generations. Millenials is a fully technological generation with great self-confidence, but at the same time an autonomous willingness to work hard, assertive and much more demanding operating with completely different and international communication tools.

Methods: The article will analyses the surveys of international research about the international crisis caused by the pandemic by methods of mathematical statistics. It has paradoxically accelerated digitization in fields where it has been difficult to assert itself so far.

Findings \& Value added:.Along with the changing behavior of the next generation and the advancing digitization and automation of work, many professions are at risk. The article deals with the possible development of the labor market in connection with the complete disappearance of some professions, but also the emergence of new professions, which now cannot even be imagined. Several weeks of quarantine, caused by a pandemic of a new type of coronavirus, has changed the lives of many companies and employees. For some companies, it meant their definitive end. For others, however, it foreshadowed the acceleration of innovation in the company itself.
\end{abstract}

Keywords: Global pandemics; innovation; labour market; competencies; mathematical and quantitative methods.

JEL Classification: $A 13 ; C 1 ; J 24 ; J 44$

\footnotetext{
${ }^{*}$ Corresponding author: linkeschova.d@ffce.vutbr.cz
} 


\section{Introduction}

History of mankind is permeated by various threatening events, such as epidemics, wars, natural disasters and crises of various kinds, including economic ones. Nevertheless, it can be stated that humanity has not yet experienced a similar situation to the pandemic caused by the new type of coronavirus in 2020.

The time of the coronavirus pandemic showed that everyone had to adapt to the current situation. "Although discussions about the implications of the COVID-19 pandemic on business are just beginning to emerge, much of what has been written treats the pandemic as a societal problem that impacts businesses, requiring them to respond to the economic consequences and consider their social responsibility to alleviate the crisis."[1] The environment of digital communication tools and the virtual world is familiar to the forthcoming generation. The crisis caused by the pandemic has paradoxically accelerated automation, digitization and robotization in the fields where it has been difficult to put them through so far. Changing behaviour of the forthcoming generation together with the advancing digitization and automation of work put many professions at risk. "Markets have changed such that firms with superior quality, lower costs, or greater innovation reap disproportionate rewards relative to prior eras."[2] Possible development of the labour market can lead to their complete disappearance, however, also to the emergence of new professions, which now cannot even be imagined.

\section{Theoretical background}

The era of digitization is becoming an integral part of our everyday life, however, in many ways we may not even have noticed it. In 2015, the digital economy accounted for $4.2 \%$ of global GDP and employed 17 million people worldwide, in addition to indirectly supporting another 15 million jobs. The period of the Fourth Industrial Revolution and the rapid changes affected by the pandemic are changing general view of work and employment as perceived nowadays, education shall not be adapted to one profession as it is now, but shall emphasize interdisciplinarity, complexity, creativity and flexibility together with strong international cooperation without restrictions by the state borders.

Working in the digital industry, construction industry as well as the other fields in the labour market requires new competences. Individuals are expected to be flexible, independent and able to solve project-oriented work tasks more and more often. In addition to professional competences, they should possess basic "skills for the 21 st century" which include, for example, the ability to (virtual) collaboration in teams made up of different experts with different responsibilities. Also important might be "exposure to innovation during childhood... as a critical factor that determines who becomes an inventor... intergenerational mobility may also be beneficial for increasing economic growth." [3] Today's employees must be able to acquire knowledge independently according to current needs - often also directly in the workplace. This requires knowledge of new media technologies and devices (web, mobile media), as well as knowledge of the risks and dangers associated with the use of data and virtual systems (security and data and data protection). However, all this is not going to work without continuous further education (lifelong learning).

While the first three stages of industrial production were characterized by innovations in mechanics (Industry 1.0), electronics (Industry 2.0) and information technology (Industry 3.0 ), it is typical for the Industry 4.0 that classical, industrial processes are increasingly interconnected with communication and data technology and create so-called cyber-physical production systems, and thus enable the realization of the vision of self-controlled production. In the broader sense of the term Industry 4.0, there is one key element - 
interconnection. Ever-increasing automation and optimization of processes in the field of production, logistics and services goes hand in hand with it.

For example, in the construction industry, the introduction of Building information modelling/management (BIM) represents such an initial step towards the digital revolution.

Generation $\mathbf{Z}$ employees prefer their own work environment - they do not like to share space with the others. Centennials value their time very much and want to know in detail the model according to which they are rewarded. They are pragmatic and are interested in non-monetary compensation in detail. The employers need to adapt motivational tools to these attitudes.

Due to the significant shortage of available, especially skilled labour force, it is necessary to change the ways of their management and control. Nowadays, people usually do not leave their jobs as such, they more often leave their managers: "People do not quit jobs, they quit managers" [4, p. 22]. There is a need to expand managerial skills, especially in technically oriented areas, with an emphasis on ethics and professionalism, time management, the ability to build trust and reliability, as well as the ability to bear risk and be creative and credible.

\section{Methodology}

The European Statistical System (ESS) guarantees the reliability of the European statistics. It includes the EU statistical office (Eurostat) and statistical offices and other institutions of the EU member states. The aim of the ESS is to provide statistical data that is harmonized, reliable, relevant and usable. Methods of statistical surveys are based on scientific statistical methods. Labour market and labour force surveys also make use of these methods. [5]

The Labour Force Sample Survey (LFSS) in the Czech Republic is conducted by the Czech Statistical Office (CSO) continuously on a randomly selected sample of households and is focused on determining the economic position of the population throughout the country.

The LFSS allows a qualified estimate of the amount of employment in organizations and companies, including the independent activities of persons doing business in accordance with the Trade Licensing Act and other legal standards.

The LFSS questionnaire in the Czech Republic has been fully harmonized with the Eurostat standard since 2002 and thus complies with Council Regulation (EC) No. 577/98. However, the content and structure of the Eurostat standard has still been evolving and in this context the CZSO makes partial adjustments to the questionnaire contents. The results of the survey serve as one of the aspects for deciding on the allocation of EU funds to the individual regions. [6]

\section{Results}

Certain innovative impulses for the labour market are based on statistical Labour Force Sample Surveys (LFSS). They are based both on the long-term trends of a naturally changing society and, more recently, on the surprising extent of the coronavirus pandemic. Upcoming innovations concern occupations, forms and models of work as well as the behaviour of the companies on the labour market.

\subsection{Professions, forms of work, company behaviour}

Many professions have become at risk due to the changing behaviour of the forthcoming generation and the coronavirus pandemic, which caused the rapidly advancing digitization and automation of work. Complete disappearance of some professions can be expected, 
together with the emergence of new professions, which now cannot even be imagined. At the same time, the current predictions rather assume that there will be fewer newly created jobs than those that have disappeared. [7]

Changes in the labour market lead to high flexibility and innovation of work regimes. Especially in offices, such forms of work as hot-desking, desk-sharing, homeworking, coworking and others are beginning to be used. Hot-desking or desk-sharing represent the physical sharing of a working place (space), not the job contents and responsibilities by multiple employees. In principle, this is an office with desks that are not assigned to specific employees. Co-working represents a shared workspace that is primarily intended for entrepreneurs. They are a suitable choice for those who, for various reasons, do not like working from home. Job-sharing is a model that is used to share one specific job position by multiple employees. It is a flexible form of work, where usually two part-time employees cover one job.

Home-working (home office) is a system of work that has been tried out by many employees in recent months and weeks. This is work from home, which has many benefits for both companies and employees. Companies save on the cost of renting offices and running them. Hybrid workspace is a hybrid work environment that is a combination of people working from home and employees working in the office. For example, companies implement the 3-2-3 model, where employees work three days from home and two days in the office and switch after a week.

\subsection{Corporate social responsibility}

Corporate Social Responsibility (CSR) means maintaining economic success and gaining a competitive advantage by building a company's reputation and gaining the trust of the people who work for it or live in the community where the company operates. Innovations can be found also in the issues of the changing role of companies in the society. At present, the public assesses and evaluates them not only according to the quality of their services and products, but also according to the degree of responsibility of their work in society. Responsible behaviour thus brings the company, in addition to strengthening the value of the brand and reputation, also greater loyalty of its employees. Good relations within the region are also important, and in connection with the situation related to coronavirus, the potential for resolving possible crisis situations also increases significantly. Socially responsible business behaviour is a long-term investment in its overall development. [8] Demands for the skills of work teams are proving to increase significantly. Key skills for the 21st century are: the ability to orientate oneself, the ability to adapt, the ability to persuade, the ability to collaborate, the ability to lead, and the ability to empathize." [9]

"International business under de-globalization would look qualitatively different from what we have seen in the past decades...there is no lack of technology that could propel globalization forward. What we do seem to lack, at this point, is a political configuration that would support this." [10]

\subsection{Impacts of anti - pandemic measures}

From April to May, 1.8 million employees experienced negative effects of the measures against the coronavirus pandemic. 1.4 million employees assumed the temporary nature of these impacts, 314 thousand were worried about their jobs.

The most significantly affected sector was accommodation, catering and hospitality, where the share exceeded $90 \%$. The $55 \%$ share appeared in the manufacturing industry, which employs the largest group of employees, as well as in finance and insurance. $67 \%$ 
share was in culture, entertainment and recreation, 53\% share was in real estate activities, a slightly above-average share (48\%) was in trade. Only a third of the employees reflecting the impacts were in information and communication technologies and in the construction industry (36\%). The calmest situation was for the employees of public administration and defence, health and social care, energy and water supply, i.e. the sectors that provide the necessary activities. Younger employees under the age of $29(21 \%)$ reflected the threat to their job the most, while those over the age of 51 reflected it the least (14\%). In the largest age group of 30-49 years, their share was $18 \%$.

$63 \%$ of entrepreneurs (self-employed persons) experienced negative effects, i.e. almost 0.5 million people. The greatest impacts were experienced in the accommodation, catering and hospitality sectors, where only $2 \%$ of them did not experience them. Education came second with $92 \%$ and other activities according to the CZ-NACE classification had a $90 \%$ share. On the other hand, less than half of the share can be found in the water supply, agriculture and health and social care. A quarter of business men and almost a third of business women described the effects of the crisis as serious. The remaining $72 \%$ of selfemployed people assume that the effects as temporary. The Czech Statistical Office has introduced an extra survey on the effects of the current crisis on the labour market as part of the Labour Force Sample Survey (LFSS) since 1 April 2020.

Employees at risk of a job loss threat divided by age (temporary impact $\mid$ job threatening impact) are in ages $15-2979 \%|21 \%, 30-4982 \%| 18 \%$ and $50+86 \mid 14 \%$. Proportion of employees experiencing problems in connection with the economic situation (2nd quarter of 2020) are over 38\% regardless of education level. [11]

A strong economic connection with Prague demonstrates itself, when a large number of Central Bohemians regularly commute to the capital for work. The share of employees perceiving the threat was also high in the Liberec Region (53.9\%), followed by Prague (49.3\%). Employees in the Hradec Králové Region (29.8\%) and the Pardubice Region $(32.2 \%)$ felt the least at risk. It is obvious that the Northeast region (Hradec Králové, Pardubice and Liberec regions) is characterized by large territorial differences in the impact of the crisis on the group of these workers.

The share of negative impacts varied greatly in terms of individual sectoral sections. The absolute highest number of employees affected by the crisis was logically in the manufacturing industry (711.4 thousand), high share was also in the trade sector. In many sectors, the share of employees at risk was around $40 \%$. On the contrary, the critical situation was in the cultural, entertainment and recreational activities sectors and especially in the sector of accommodation, catering and hospitality.

In terms of the share of being affected according to education, most of them were among employees with primary education (45.3\%) and secondary education without a Maturita school leaving exam (46.1\%). With increasing education level, the proportion of affected people decreased.

Some proportion of employees experiencing problems in connection with the economic situation in individual regions (2nd quarter of 2020) we can find in \% [12]

The negative effects of the current situation on the economy, sales or the volume of work and orders are experienced by the majority $(60 \%)$ of self-employed persons or entrepreneurs. This represents 514 thousand persons. From a regional point of view, entrepreneurs in the Central Bohemian Region and in Prague most often expressed concern.

In percentage terms, the most common positive answers to the question of experiencing impacts were in education (95\%), accommodation and hospitality (94\%) and in the sector other activities (86\%). The smallest share was in entrepreneurs in agriculture (34\%). Numerically, the self-employed in the construction industry dominated, as the self-employed are most involved in this sector. There were also high numbers in the trade and repair sectors, 
which was related to closed establishments, as well as in professional, scientific and technical activities.

Significant differences between the sexes were in the answers in contrast to the employees. More significant concerns were found among women entrepreneurs, where $64 \%$ experienced the effects compared to $58 \%$ of men. Women also considered the situation to be more serious - almost a third of women considered the effects to be serious (threatening their business), while only one quarter of men entrepreneurs shared this opinion. The young women experienced the impacts the most (around 75\%) and with increasing age the proportion of positive answers among women decreased by half. On the contrary, the tendency was slightly increasing for men, only about $50 \%$ of young men and about $60 \%$ in the highest age categories. The assessment of the severity of the impact on business decreased very slightly with age for both sexes. If self-employed persons experienced negative impacts, then they were most often considered serious and threatening their business by persons doing business in the last segment of distribution of goods, i.e. wholesale and retail trade and maintenance and motor vehicles and motorcycles repair sector. [5]

In the 2nd quarter of 2020, the labour market was significantly affected by the effects of unprecedented anti-epidemic measures, which, however, the market gradually began to cope with as well as changes its structure. The impact of self-employed was over $34 \%$ for women with basic education and 58\% for self-employed with university degree. [11] Most impacted were self-employed women both with and without college degree over $65 \%$. The sectoral development was therefore significantly differentiated. Overall, the average wage increased by $0.5 \%$ in nominal terms, however, at the same time the prices rose sharply, so that real earnings fell by $2.5 \%$.

The most characteristic results describing the course of the coronavirus pandemic crisis were data on hours worked by individual months based on the Labour Force Sample Survey (LFSS).

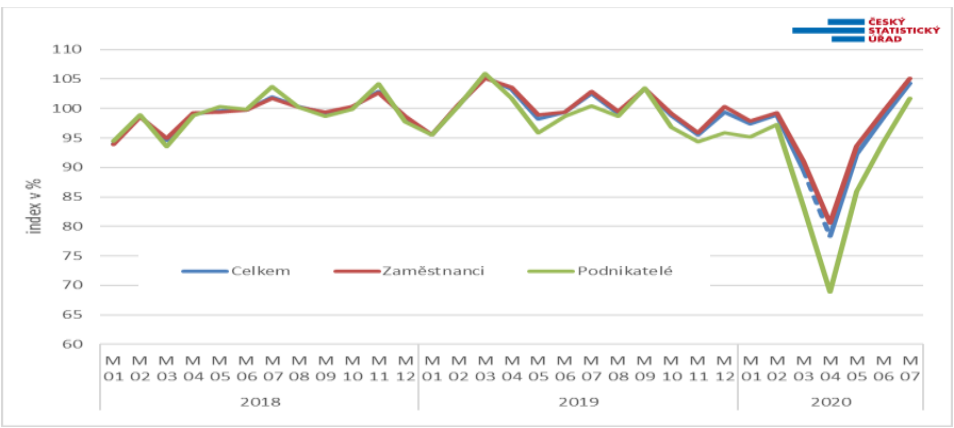

Fig. 1. Hours actually worked per week in the main job from the LFSS and the index for the same period of the previous year [13]

According to a revised estimate, gross domestic product fell by $8.7 \%$ quarter-on-quarter and by $11.0 \%$ year-on-year in the 2 nd quarter. The negative development of the GDP was mainly due to a decline in foreign demand. A more accurate estimate confirmed the historically worst performance of the Czech economy. Price and seasonally adjusted gross domestic product (GDP) [8] decreased by $8.7 \%$ compared to the previous quarter. Year-onyear, GDP decreased by $11.0 \%$.

Gross value added (GVA) was by $9.4 \%$ lower quarter-on-quarter. There was a decrease in GVA in all branches of the economy, in manufacturing industry by $14.7 \%$, in the group of trade, transport, accommodation and food service sector by $17.5 \%$ and in other activities by $23.1 \%$. Year-on-year, GVA decreased by $10.9 \%$. The decrease in GVA creation was mostly influenced by the development in the manufacturing industry (negative contribution $-4.6 \mathrm{pp}$, 
decrease by $18.2 \%$ ) and in the sector of trade, transport, accommodation and food services ($3.8 \mathrm{pp}$, decrease by $20.5 \%$ ). A positive contribution was recorded by the information and communication technology sector $(0.1 \mathrm{pp}$, with a growth by $1.1 \%)$.

In the 2 nd quarter of 2020 , the average gross monthly nominal wage per recalculated number of employees in the national economy increased by $0.5 \%$ compared to the same period of the previous year, however, it decreased by $2.5 \%$ in real terms. The median wage was CZK 29,123.

In the 2nd quarter of 2020, the average gross monthly nominal wage (hereinafter referred to as the "average wage") per recalculated number of employees in the national economy totalled at CZK 34,271, which is by CZK $160(0.5 \%)$ more than in the same period of 2019. Consumer prices increased by $3.1 \%$ over the same period, so the real wage decreased by $2.5 \%$. The volume of wages decreased by $2.9 \%$, the number of employees decreased by $3.4 \%$.

Compared to the previous quarter, the decline in the average wage in the 2 nd quarter of 2020, seasonally adjusted, was $3.1 \%$.

The median wage (CZK 29,123) decreased by $0.2 \%$ compared to the same period of the previous year, reaching CZK 31,450 for men and CZK 26,489 for women. 80\% of employees received wages between CZK 14,659 and CZK 56,263.

In the first half of 2020, the average wage reached CZK 34,200, a year-on-year increase by CZK $909(2.7 \%)$. Consumer prices increased by $3.4 \%$ over the period, real wages decreased by $0.7 \%$.

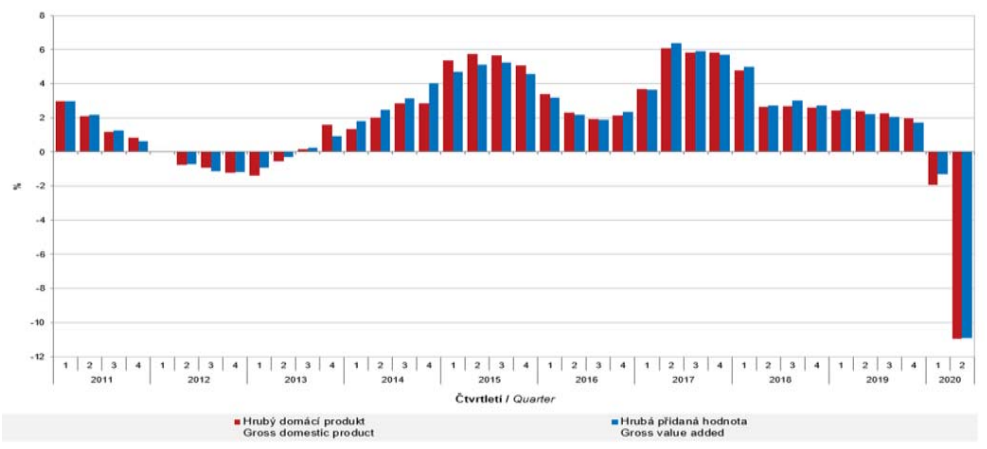

Fig. 2. Gross domestic product and gross value added - year-on-year real change, seasonally adjusted [14]

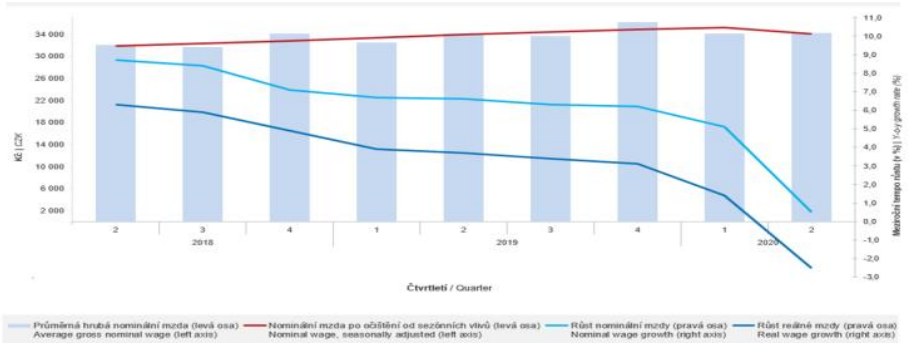

Fig. 3. Average monthly wage - quarterly data (absolute values and monthly changes) [15] 


\section{Discussion}

\subsection{Measures to limit the spread of Covid -19 in Europe}

The Covid-19 virus hit Europe in January and February, with the first cases confirmed in Spain, France and Italy. Covid-19 infection has now been diagnosed in all Member States of the European Union.

EU Member States have taken a wide range of measures to combat the pandemic. Since 17 March, EU Member States have introduced temporary restrictions on insignificant travel from third countries to the EU (exceptions have been set for nationals of all EU Member States and Schengen Associated States). Most countries have also introduced restrictions on movement between Member States. Some "workers are discouraging some firms from adopting".[16]

In the second week of March, schools were closed in most Member States. Public events were cancelled by almost all Member States and private events (with a number of people ranging from 2 to 50) were banned. Bars, restaurants and hotels were closed in almost all countries. In addition, most countries closed retail outlets, with the exception of supermarkets, pharmacies and banks. In Italy and Spain, insignificant production was stopped and several countries introduced regional or even national blocking measures, which further stifled economic activities in many areas. "We use the 2008-2009 global financial crisis as such a shock. As they argue and find, the financial crisis revealed the financial value of firm-level social capital and trust" [17]

"There appear to be negative shocks to the stock market that occur at business cycle frequencies, are associated with high realized volatility and declines in output, and are priced strongly by investors." [18]

This "long-short return predictability is similar across most developed stock markets."[19]The vast majority of preventive measures were taken in mid-March. Most precautionary measures and restrictions were maintained throughout April. In May and June, most measures were completely or partially cancelled, resulting in an increase in productive service activities. However, the pre-crisis level of service production has not yet been restored.

\subsection{Development of service production in June 2020}

Figure 9 shows the March and April declines in the production of services for total services and for different groups of services, as well as a partial recovery in May and June. It should be taken into account that financial, insurance and public services are not included.

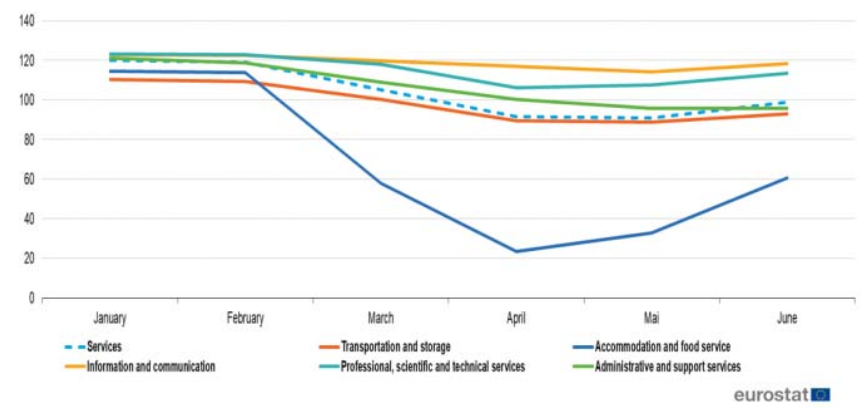

Fig. 4. Development of services in the January to June 2020 period in the EU-27 [11]

In June 2020, the volume of service output in the EU-27 increased by $8.6 \%$ compared to May 2020. In May 2020, service output remained relatively stable (-0.5\%), however, in the previous months of April and March the crisis led to significant losses in the output of 
services (-11.7\% in March and $-13.0 \%$ in April). In the euro area, developments were similar. The strongest decline during the Covid-19 pandemic crisis (April compared to February) was recorded for accommodation and food services (hotels and restaurants), which fell by $79.3 \%$ in the EU-27. Transport services (land, water, air) decreased by 18.0\%. Administrative and support service activities (e.g. employment services, security, cleaning), which are usually purchased by companies, decreased by $15.7 \%$. Professional and scientific services (legal services, accounting, marketing, etc.) decreased by $13.7 \%$. Information and communication technology services fell by a relatively modest pace by $4.3 \%$. [20]

\section{Conclusion}

The current closely interconnected digital world offers a wide choice of benefits that we all were aware of during the global pandemic. We were able to stay in contact with distant friends, relatives and co-workers, shop remotely and enjoy collected cultural goods from around the world. However, it is necessary to realize that this also opens door to global competition. Also "young workers manage to obtain on average about 82 per cent of their potential earnings three years after leaving full-time education"[21]If we provide education and a significant part of work remotely, we must reckon with the fact that our work can be transferred to the third world countries. There is a danger for Czech and Slovak universities of the outflow of students to more prestigious western universities. If it is possible to study without borders via the Internet, our language barrier will deepen and there will be a greater outflow of young skilled workers in particular from the labour market. The ,post-work future are: rise of automation, AI, machine intelligence moving toward a future where people are less necessary for work; shifts in individual values... which are determined by the central role of work in social life. Jobs are central to an individual's identity, but are slowly becoming less significant. Jobs provide structure to daily life, but the structure of daily life itself is being challenged by changes in technology and the economy."[22]"Employee consensus is a critical outcome...consensus amplifies the positive effects of high involvement work systems on firm-level innovation."[23]"Global challenges cannot be solved globally. We can see them clearly. We understand their fundamental causes. We have proven methods to solve them. However, we refuse to make compromises, cooperate and solve these problems consistently - it is up to us, local, not global leaders. We can lead people to make positive changes locally, make life easier and more sustainable, and open up new opportunities in the times of global decline. "[24]"Hope is not the belief that something will turn out well, but the certainty that something will make sense - no matter how it turns out." Václav Havel.

\section{References}

1. Bapuji, H., Patel, C., Ertug, G., Allen, D.G. (2020) Corona Crisis and Inequality: Why Management Research Needs a Societal Turn. Journal of Management, 46(7), 12051222.

2. Autor, D., Dorn, D., Katz, L.F., Patterson, C., Van Reenen, J. (2020). Antecedents and outcomes of objective versus subjective scientific The fall of the labor share and the rise of superstar firms. Quarterly Journal of Economics, 135(2), 645-709.

3. Bell, A., Chetty, R., Jaravel, X., Petkova, N., Van Reenen, J. (2019), Who becomes an inventor in america? The importance of exposure to innovation. Quarterly Journal of Economics, 134(2), 647-71.

4. Hess, D.W. (2018) Leadership by Engineers and Scientists (Professional Skills Needed to Succeed in a Changing World). New Jersey: John Wiley \& Sons.

5. Český statistický úrud (2018, Feb 7) Co je ESS a jak pracuje. ČSÚ. Retrieved from: https://www.czso.cz/csu/czso/co_je_ess_a_jak_pracuje 
6. Český statistický úřad (2020, Sep 9) Výběrové šetření pracovnich sil - VŠPS. ČSÚ. Retrieved from: https:/www.czso.cz/csu/xc/vyberove_setreni_pracovnich_sil_vsps

7. Chmelar, A., Volcik, S., Nechuta, A., Holub, O. (2017, Sep 18) Dopady digitalizace na trh práce $v \check{C} R$ a $E U$. Oddělení strategie a trendů Evropské unie (OSTEU). Retrieved from: $\quad$ https://www.vlada.cz/assets/evropske-zalezitosti/analyzy-EU/Dopadydigitalizace-na-trh-prace-CR-a-EU.pdf

8. BPS Byznys pro společnost, z.s. (2020, Feb 3) Co je společenská odpovědnost firem. Standard Odpovědná Firma (LBG). Retrieved from: http://www.businessprospolecnost.cz/lbg/spolecenska-odpovednost-firem.html

9. HK ČR Hospodářská komora ČR. (2019). Revoluce práce je tu. Komora, měsíčník hospodářské komory České republiky, 2, 80.

10. Witt, M.A. (2019). De-globalization: Theories, predictions, and opportunities for international business research. Journal of International Business Studies, 50(7), 10531077.

11. Český statistický úřad (2020, Aug 8) Většina pracujicích vidí dopady krize jako dočasné. ČSÚ. Retrieved from: https://www.czso.cz/csu/czso/cri/vetsina-pracujicich-vididopady-krize-jako- docasne-2-ctvrtleti-2020

12. Český statistický úruad (2020, Aug 8) Zaměstnanost a nezaměstnanost podle výsledků VŠPS - Metodika. ČSÚ. Retrieved from: https://www.czso.cz/csu/czso/zam_vsps

13. Český statistický úřad (2020, Sep 3) Vývoj českého trhu práce - 2. čtvrtletí 2020. ČSÚ. Retrieved from: https://www.czso.cz/csu/czso/cri/vyvoj-ceskeho-trhu-prace-2-ctvrtleti2020

14. Český statistický úřad (2020, Sep 1) Tvorba a užití HDP - 2. čtvrtletí 2020. ČSÚ. Retrieved from: https://www.czso.cz/csu/czso/cri/tvorba-a-uziti-hdp-2-ctvrtleti-2020

15. Český statistický úřad (2020, Sep 3) Prưměrné mzdy - 2. čtvrtletí 2020. ČSÚ. Retrieved from: https://www.czso.cz/csu/czso/cri/prumerne-mzdy-2-ctvrtleti-2020

16. Atkin, D., Chaudhry, A., Chaudry, S., Khandelwal, A.K., Verhoogen, E. (2017). Organizational barriers to technology adoption: Evidence from soccer-ball producers in pakistan. Quarterly Journal of Economics, 132(3), 1101-1164.

17. Dyck, A., Lins, K.V., Roth, L., Wagner, H.F. (2019) Do institutional investors drive corporate social responsibility? International evidence. Journal of Financial Economics, 131(3), 693-714.

18. Berger, D., Dew-Becker, I., Giglio, S. (2020) Uncertainty Shocks as Second-Moment News Shocks. Review of Economic Studies, 87(1), 40-76.

19. Jacobs, H. and Muller, S. (2020) Anomalies across the globe: Once public, no longer existent? Journal of Financial Economic, 135(1), 213-230.

20. Statistics Explained (2020, Sep 3) Impact of Covid-19 crisis on services. EUROSTAT. Retrieved from: https://ec.europa.eu/eurostat/statisticsexplained/index.php?title=Impact_of_Covid19_crisis_on_services\#Development_by_c ountry

21. Bazen, S., Maman Waziri, K. (2019). The integration of young workers into the labour market in France. International Journal of Manpower, 41(1), 17-36.

22. Hines, A. (2019). Getting Ready for a Post-Work Future. Foresight and STI Governance, 13(1), 19-30.

23. Weller, I., Suess, J., Evanschitzky, H., von Wangenheim, F. (2020), Transformational Leadership, High-Performance Work System Consensus, and Customer Satisfaction. Journal of Management, 46(8), 1469-1497.

24. Wheatleyova, M.J. (2020). Vědomý lídr, Prague: MAITREA. 